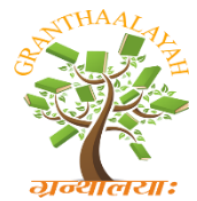

INTERNATIONAL JOURNAL OF RESEARCH GRANTHAALAYAH A knowledge Repository

Science

\title{
COMPARATIVE EFFECTS OF PEER TUTORING AND EXPLICIT INSTRUCTIONAL STRATEGIES ON SCIENCE AND TECHNICAL COLLEGE STUDENTS' ACHIEVEMENT AND RETENTION IN NASARAWA STATE, NIGERIA
}

\author{
Agu Peter Ashlame 1, Samuel Ruth Iwanger ${ }^{2}$ \\ ${ }^{1,2}$ Department of Science, Technology and Mathematics Education, Faculty of Education, \\ Nasarawa State University, Keffi, Nigeria
}

\begin{abstract}
This study investigated the effects of Peer Tutoring and Explicit instructional strategies on Science and Technical college students' achievement and retention in Nasarawa State, Nigeria. Quasiexperimental, non-equivalent pretest, post-test, post-post-test control group design was employed for the study. The population consisted of 1,237 Science and Technical college students. The sample of the study comprised 67 Science and Technical College students purposively sampled from two intact classes randomly selected from the three Science and Technical colleges in Nasarawa State, Nigeria. Two research questions and two research hypotheses guided the study. Science and Technical Achievement Test (STAT) was used as instrument for data collection. It reliability was determined using Kuder-Richardson formula 20 (KR20) and the reliability coefficient of 0.83 was obtained. Mean and Standard Deviation were used to answer the research questions while Analysis of Covariance (ANCOVA) was used to test the research hypotheses at 0.05 alpha level of significance. Bonferroni Multiple Comparisons was used to determine the direction of the difference. The findings of this study revealed that Peer Tutoring and Explicit instructional strategies have significant effect on Science and Technical college students' achievement and retention. Based on the findings of this study, it was recommended that; Science and Technical college teachers should incorporate Peer Tutoring and Explicit instructional strategies into the teaching of Science and Technical subjects.
\end{abstract}

Keywords: Achievement; Explicit; Peer Tutoring; Retention; Science and Technical College.

Cite This Article: Agu Peter Ashlame, and Samuel Ruth Iwanger. (2019). "COMPARATIVE EFFECTS OF PEER TUTORING AND EXPLICIT INSTRUCTIONAL STRATEGIES ON SCIENCE AND TECHNICAL COLLEGE STUDENTS' ACHIEVEMENT AND RETENTION IN NASARAWA STATE, NIGERIA." International Journal of Research - Granthaalayah, 7(10), 390-399. https://doi.org/10.29121/granthaalayah.v7.i10.2019.409. 


\section{Introduction}

The function of Science and Technology in the reformation and transformation of any country is of uttermost importance. Science and technology have greatly affected the life of every human being so much that it will also be difficult for a nation with a scientifically illiterate citizenry to make any reasonable technically-based political decision on issues of everyday life such as the environment, agriculture, health, transport and communication or population growth. This is so because such a nation would lack the rudimentary tools and knowledge to grasp the various arguments that are necessary for taking such decisions (Kabutu, Oloyede \& Bandele, 2015).

The paramount function of science and technology in contemporary society is indispensable to the healthy existence of any nation. In realization of the function of science and technology for national development, the Federal Government of Nigeria (FRN, 2014) in its National Policy on Education (NPE) gave a special place to science, technology and mathematics education in a bid to promote scientific literacy of her citizenry. In addition, the government has put in place some reforms and measures aimed at harnessing the human and material resources in the country. Prominent among the reforms is the National Policy on Science and Technology that spells out objectives and direction of science and technology education in Nigeria. Among the objectives is Human Resource Development (HRD) in Science, Technology and Innovation. The rationale is stated in sub-section 3.2 of National Policy on Science and Technology (FRN, 2012) which that stipulates the imperatives of self-sufficiency and global competitiveness require development of national capability in Science, Technology and Innovation aimed at stimulating inventions and generating innovations for sustainable development. The ultimate objective is to develop capacity in Science, Technology and Innovation for competitiveness in the production of technological goods and services.

The introduction of science and technology at all levels of education in the country be it elementary, secondary, and tertiary education is deliberately designed to position talented citizens to acquire the skills and knowledge necessary for effective contribution national development (Osokoya, 2013; Bukunola \& Idowu, 2012). This move by the government is very strategic in the sense that even if students do not further their study of science and technology in tertiary institutions and as a result do not go on to become professional scientists, engineers, and technologists, their experience of science and technology gained from the elementary and secondary levels and first year of their tertiary education would be sufficiently rich and relevant. Such scientific literacy will equip them to contribute to the country's development in an increasingly competitive and rapidly changing world (Oni, 2014 \& Oludipe, 2012).

Despite the relevance of science and technology to national development, security, economy, manpower and government's efforts to improve science instruction in schools, students' achievement in its subjects is below average. This has become a great concern for Science and Technology educators especially at the foundational level. Researchers such as Bukunola and Idowu (2012), Osokoya (2013), Alabi (2014), Oni (2014), Kabutu, Oloyede and Bandele (2015), Samuel (2017), Nwadinigu and Azuka-Obieke (2012), Igoegwu and Okonkwo (2012), Amoo, (2013) and Kola and Taiwo (2013) opined that underachievement in science, technology and mathematics among secondary school students could be attributed to several factors such as poor teaching, psychological factors, unpreparedness on the part of the students, poor learning 
environment, school location, gender stereotyping, dearth of qualified teachers among others. As a result of the decline in science, technology and mathematics students' achievement, stakeholders in the sector agree that the huge investment in science and technology education is not yielding the desired dividend. Agu and Samuel (2018), Eriba and Samuel (2018) observed that poor instructional strategies employed in the teaching of science and technical subjects by teachers contribute to students' under-achievement because students find it difficult to understand the concepts taught. In order to achieve the objectives of Science and Technology education, the student-activity-based mode of teaching strategies have been recommended by the FRN (2014).

\section{Review of Literature}

Moreneo and Duran (2002) described peer tutoring as a form of cooperative learning where students are grouped into pairs but not necessarily with the same academic disposition; that is, the tutor and tutee do not have equal academic ability but work to achieve the same goal. The teacher in this situation works as a facilitator to ensure that the students This goal must be achieved through a relationship framework organised by the teacher. The method is regarded as an excellent resource for facilitating the mastery of interpersonal competencies. Fuchs, Fuchs, Mathes, and Martinez (2002) asserted that socialisation experiences that occur during peer tutoring can be of benefit to both the tutor and the tutee by encouraging students to learn and increase their social profile among peers. Peer tutoring has been found to be helpful in providing socialization experience to students both inside and outside the classroom. Peer tutoring is also important for the tutor; that is, learning is encouraged through teaching. Hartman (2010) conducted an evaluation study and reported that peer tutoring increased students' motivation to learn. This result is supported by Whitman (2012) and Annis (2013) who stated that peer tutoring can be the most intellectually rewarding experience of a student's career. They found that peer tutoring helped students perform better on higher order conceptual understanding scales than students who read the material simply for study purposes. Oviawe (2008) also observed that peer tutoring an effective way of improving self-esteem in students. Researchers such as (Samuel \& Sambo, 2018; Agu and Samuel (2018), Agboola and Oloyede (2013) and Agoro (2012) found out that the use of Peer Tutoring improved students' interaction among peers not only socially but also academically, hence boosting academic achievement.

Explicit teaching is a form of teaching where students are directed toward specific learning in an organized and structured environment. This teaching method focuses on producing specific learning outcomes. Topics and contents are broken down into small parts and taught individually. The method makes use of explanation, demonstration and practice to provide guidance to children under a structured framework. Topics are taught in a logical order and directed by the teacher (Gauthier, Mellouki, Simard, Bissonnette \& Richard, 2004).

Explicit teaching also involves modeling behaviour, skills, and thinking processes. In this model, the teacher thinks out loud as he works through problems and demonstrates processes for students. The attention of students is important and listening and observation are key to success. Explicit teaching is useful for introducing topics and specific skills. It provides guided instruction in the basic understanding of required skills, which students can then build on through practice, collaboration, repetition, hands on activities and developmental play (Bissonnette, Richard, Gauthier \& Bouchard, 2010). Researchers such as Olagunju and Babayemi (2014) and Ajila (2003) 
found that the use of Explicit Instructional strategy is effective in science classroom as it enhances achievement among Science students.

According to Gauthier, Bissonnette and Richard (2013), explicit instruction can be divided into three sequential steps namely, modeling, guided or directed practice, and independent practice. The modeling step promotes the understanding of the learning objectives for students. Guided practice allows students to practice using the technique and to consolidate their understanding through group work. Independent practice provides students with learning opportunities to acquire and master the target skills. The authors provide the following analysis of the explicit teaching method step by step:

- Explicit instruction begins with modeling. This step consists of the teacher demonstrating a task for students and describing exactly what is being done as it is being done. The goal of the modeling step is for the teacher to explicitly state the what, why, how, when and where of what they are doing. The information is presented in small units, in a graduated sequence, usually ranging from simple to more complex, not only to meet the working memory limitations of students, but also to enhance the connections between new and prior knowledge. The teacher can then use examples of what to do and what not to do to more directly highlight the skills they are trying to teach to students, to facilitate their understanding of the learning objectives and thus improve the quality of modeling.

- After modeling, the next step of explicit instruction is guided practice, also referred to as directed practice, which allows students (with the proper supports) to succeed in achieving the desired learning objectives. It also helps students to gain the confidence and motivation necessary to continue their learning. This step is conducive to group work activities, which gives the teacher the opportunity to circulate and confirm that all students have understood the lesson. It also allows students not only the opportunity to try the tasks that were modeled, but ensures that they receive feedback on their finished work. Guided practice helps students to "verify, adjust, consolidate and to deepen their understanding of the learning taking place, by connecting their new learning with that which is already present in their long term memories".

- Finally, independent practice allows students to put themselves in new learning situations where they can apply what they have understood from the modeling and guided practice steps. This final learning step provides students an opportunity to test out their understanding in order to obtain the highest level of mastery possible, with the goal of consolidating their learning. This step also identifies any students who may be in need of some additional support before they move on.

Achievement is a measure of how successfully a student has accomplished a given academic task after teaching. Its purpose is to find out the stand of a student at a given moment (Akani, 2017). It has to do with the measure of knowledge acquired by the student which helps the teacher and the student to evaluate and predict the degree of learning attained. It is useful in testing the retention of information and skill. It is also a determinant of the efficacy and efficiency of a given instruction (Kabutu, Oloyede \& Bandele, 2015).

Retention is the capability to replicate a concept or skill learnt when the need arises. It is the ability to reproduce a learned behaviour by the learner soon or long after it has been learnt. Therefore, a learner who repeats an acquired knowledge with less error is said to have retained the material 
learnt. Similarly, when what is not retained or fades with time, learning becomes incomplete. Learning is said to have occurred when what is learnt remains relatively permanent in the mind of the learner. Hence, it is pertinent for students to retain what is learnt. Exploring mode of lesson delivery which could help students retain materials learnt becomes absolutely important (Asogwa, Muhammed, Asogwa \& Ofoegbu, 2016).

The persistent underachievement of Science and Technical students has become disturbing. This study determined the extent to which classroom exposures of students to Peer tutoring and Explicit Instructional Strategies could enhance Science and Technical college students' achievement and retention. Specifically, this study sought to find out:

1) effect of Peer Tutoring and Explicit Instructional Strategies on Science and Technical College students' achievement.

2) effect of Peer Tutoring and Explicit Instructional Strategies on Science and Technical College students' retention.

\section{Research Questions}

The following research questions guided this study:

1) What is the effect of Peer Tutoring and Explicit Instructional Strategies on Science and Technical College students' achievement?

2) What is the effect of Peer Tutoring and Explicit Instructional Strategies on Science and Technical College students' retention?

\section{Research Hypotheses}

The following hypotheses were tested at 0.05 level of significance:

Ho1: There is no significant difference in the mean achievement scores of Science and Technical College students taught using Peer Tutoring and Explicit Instructional Strategies.

Ho2: There is no significant difference in the mean retention scores of Science and Technical College students taught using Peer Tutoring and Explicit Instructional Strategies.

\section{Methodology}

Quasi-experimental, non-equivalent pretest, post-test, post-post-test control group design was employed for the study. The population consisted of 1,237 (675 males and 562 females) Science and Technical College students in the three (3) Science and Technical Colleges in Nasarawa State, Nigeria, viz Assakio, Agwada and Mada station. The sample of the study comprised 67 Science and Technical College students purposively sampled from two intact classes randomly selected from the three Science and Technical colleges in Nasarawa State, Nigeria. The experimental groups I $(n=35)$ and II $(n=32)$ were taught using Peer Tutoring and Explicit Instructional Strategies respectively. Science and Technical Achievement Test (STAT) was used as instrument for data collection. STAT consisted of 30 multiple choice items with 4-options A-D designed to measure students' achievement and later reshuffled to measure students' retention. The instrument was subjected to content and face validity by two experts in Science Education from Nasarawa State University, Keffi, Nasarawa State and Technology Education, Federal University of Technology, Minna, Niger State. Its reliability was determined using Kuder-Richardson formula $20\left(\mathrm{KR}_{20}\right)$ and this yielded a reliability coefficient of 0.83 . Mean and Standard Deviation were used to answer the 
research questions while Analysis of Covariance (ANCOVA) was used to test the research hypotheses at 0.05 alpha level of significance.

\section{Result}

\section{Research Question One}

What is the effect of Peer Tutoring and Explicit Instructional Strategies on Science and Technical College students' achievement?

The data used to answer this research question is presented in Table 1.

Table 1: Means and Standard Deviation of Science and Technical College Students' Achievement Scores Exposed to Peer Tutoring and Explicit Instructional Strategies

\begin{tabular}{|l|l|l|l|r|l|}
\hline Group & Type of Test & N & Mean & SD & Mean Gain \\
\hline Peer Tutoring Instructional Strategy & Pre-test & 35 & 16.71 & 0.69 & 15.17 \\
\hline & Post-test & 35 & 31.88 & 0.95 & \\
\hline Explicit Instructional Strategy & Pre-test & 32 & 13.61 & 0.65 & 16.18 \\
\hline & Post-test & 32 & 29.79 & 0.96 & \\
\hline
\end{tabular}

Table 1 shows that mean gain of the achievement scores of Science and Technical College students exposed to Peer Tutoring instructional strategy is 15.17 while those exposed to Explicit instructional strategy is 16.18. This shows that those taught using Explicit instructional strategy achieved higher than those who were taught using Peer Tutoring instructional strategy.

\section{Research Question Two}

What is the effect of Peer Tutoring and Explicit Instructional Strategies on Science and Technical College students' achievement?

The data used to answer this research question is presented in Table 2.

Table 2: Means and Standard Deviation of Science and Technical College Students' Retention Scores Exposed to Peer Tutoring and Explicit Instructional Strategies

\begin{tabular}{|l|l|l|l|r|l|}
\hline Group & Type of Test & N & Mean & SD & Mean Diff. \\
\hline Peer Tutoring Instructional Strategy & Post-test & 35 & 31.88 & 0.95 & 6.48 \\
\hline & Post-Posttest & 35 & 25.40 & 0.85 & \\
\hline Explicit Instructional Strategy & Post-test & 32 & 29.79 & 0.96 & 3.82 \\
\hline & Post-Posttest & 32 & 25.97 & 0.84 & \\
\hline
\end{tabular}

Table 2 shows that mean difference of the retention scores of Science and Technical College students exposed to Peer Tutoring instructional strategy is 6.48 and those exposed to Explicit instructional strategy is 3.82. This shows that those taught using Peer Tutoring instructional strategy retained more than those who were taught using Explicit instructional strategy.

\section{Hypothesis One}

There is no significant difference in the mean achievement scores of Science and Technical College students taught using Peer Tutoring and Explicit Instructional Strategies

The data used to test this hypothesis is presented in Table 3. 
Table 3: Result of Analysis of Covariance of Science and Technical College Students'

Achievement Using STAT

\begin{tabular}{|l|l|l|l|l|l|}
\hline Source of Variation & Sum of Square & Df & Mean Square & F & Sig \\
\hline Corrected Model & 3542.486 & 2 & 126.141 & 3.203 & .000 \\
\hline Intercept & 2611.711 & 1 & 2611.711 & 278.951 & .000 \\
\hline Pre-test & 9.879 & 1 & 9.879 & 2.010 & .000 \\
\hline Group & 28.171 & 1 & 28.171 & 15.105 & .000 \\
\hline Error & 401.741 & 62 & & & \\
\hline Total & 6593.988 & 67 & & & \\
\hline
\end{tabular}

Table 3 shows that the ANCOVA test $(F)=15.105, p<0.05$. This implies that there is a significant difference in the mean achievement scores of Science and Technical College students exposed to Peer Tutoring and Explicit instructional strategies. Based on the established difference in the achievement scores of the groups, Bonferroni Multiple Comparisons was used to determine the direction of the difference. The results of this comparison are shown in Table 4.

Table 4: Bonferroni Multiple Comparisons Results of Students' Mean Achievement Scores

\begin{tabular}{|c|c|c|c|c|c|c|}
\hline \multirow[t]{2}{*}{ (I) Group } & \multirow[t]{2}{*}{ (J) Group } & \multirow[t]{2}{*}{$\begin{array}{l}\text { Mean Difference } \\
\text { (I-J) }\end{array}$} & \multirow[t]{2}{*}{$\begin{array}{l}\text { Std. } \\
\text { Error }\end{array}$} & \multirow[t]{2}{*}{ Sig. $b$} & \multicolumn{2}{|c|}{$\begin{array}{c}\text { 95\% Confidence Interval for } \\
\text { Difference }^{b}\end{array}$} \\
\hline & & & & & Lower Bound & Upper Bound \\
\hline \multirow{2}{*}{$\begin{array}{l}\text { Peer } \\
\text { Tutoring }\end{array}$} & Explicit & $4.748^{*}$ & .552 & .000 & 3.275 & 6.221 \\
\hline & & & & & & \\
\hline \multirow{2}{*}{ Explicit } & & & & & & \\
\hline & $\begin{array}{l}\text { Peer } \\
\text { Tutoring }\end{array}$ & $4.331^{*}$ & .578 & .000 & 2.790 & 5.873 \\
\hline & & & & & & \\
\hline
\end{tabular}

Table 4 shows that there is a significant difference between the mean achievement scores of Science and Technical College students exposed to Peer Tutoring and Explicit instructional strategies in favour of the Explicit group. Therefore, the null hypothesis was rejected.

\section{Hypothesis Two}

There is no significant difference in the mean retention scores of Science and Technical College students taught using Peer Tutoring and Explicit Instructional Strategies.

The data used to test this hypothesis is presented in Table 5.

Table 5: Result of Analysis of Covariance of Science and Technical College Students' Retention Using STAT

\begin{tabular}{|l|l|l|l|l|l|}
\hline Source of Variation & Sum of Square & Df & Mean Square & F & Sig \\
\hline Corrected Model & 498.117 & 2 & 140.131 & 5.003 & .001 \\
\hline Intercept & 147.071 & 1 & 147.071 & 121.210 & .003 \\
\hline Post-test & 17.821 & 1 & 17.821 & 4.707 & .000 \\
\hline Group & 34.053 & 1 & 34.053 & 28.629 & .001 \\
\hline
\end{tabular}




\begin{tabular}{|l|l|l|l|l|l|}
\hline Error & 428.040 & 62 & & & \\
\hline Total & 1125.102 & 67 & & & \\
\hline
\end{tabular}

Table 5 shows that the ANCOVA test $(F)=28.629, p<0.05$. This implies that there is a significant difference in the mean retention scores of Science and Technical College students exposed to Peer Tutoring and Explicit instructional strategies. Therefore, the hypothesis was rejected. Based on the established difference in the retention scores of the groups, Bonferroni Multiple Comparisons was used to determine the direction of the difference. The results of this comparison is shown in Table 6.

Table 6: Bonferroni Multiple Comparisons Results of Students' Mean Retention Scores

\begin{tabular}{|c|c|c|c|c|c|c|}
\hline \multirow[t]{2}{*}{ (I) Group } & \multirow[t]{2}{*}{ (J) Group } & \multirow[t]{2}{*}{$\begin{array}{c}\text { Mean Difference } \\
\text { (I-J) }\end{array}$} & \multirow{2}{*}{\multicolumn{2}{|c|}{\begin{tabular}{c|c|} 
Std. & Sig.b \\
Error &
\end{tabular}}} & \multicolumn{2}{|c|}{$\begin{array}{c}\text { 95\% Confidence Interval for } \\
\text { Difference }^{b}\end{array}$} \\
\hline & & & & & Lower Bound & Upper Bound \\
\hline \multirow{2}{*}{$\begin{array}{l}\text { Peer } \\
\text { Tutoring }\end{array}$} & Explicit & $3.160^{*}$ & .568 & \multicolumn{2}{|c|}{\begin{tabular}{|l|l|l|l}
.000 & 1.432 \\
\end{tabular}} & 1.099 \\
\hline & & & & & & \\
\hline \multirow[t]{2}{*}{ Explicit } & & & & & & \\
\hline & $\begin{array}{l}\text { Peer } \\
\text { Tutoring }\end{array}$ & $3.533^{*}$ & .532 & \multicolumn{2}{|c|}{\begin{tabular}{l|l|}
.000 & 2.132
\end{tabular}} & 1.021 \\
\hline
\end{tabular}

Table 6 shows that there is a significant difference between the mean retention scores of Science and Technical College students exposed to Peer Tutoring and Explicit instructional strategies in favour of the Peer Tutoring group. Therefore, the null hypothesis was rejected.

\section{Discussion}

The findings of this study revealed that there was significant difference between the achievement scores of Science and Technical college students exposed to Peer Tutoring and Explicit instructional strategies in favour of the Explicit instructional group. The findings of this study also revealed that there was a significant difference between the retention scores of Science and Technical College students exposed to Peer Tutoring and Explicit instructional strategies in favour of the Peer Tutoring instructional group. These findings are in agreement with that of Samuel and Sambo (2019), Agu and Samuel (2018), Olagunju and Babayemi (2014), Agboola and Oloyede (2013), Agoro (2012), Okilwa (2011) and Ajila (2003) who in separate research studies found that Peer Tutoring and Explicit instructional strategies enhances students' achievement and retention. The increase in students' achievement and retention scores could probably be because they were excited to have acted like teachers and given opportunities to teach and learn among their peer groups. Apparently, teaching, instructing, demonstrating and presenting instructions like their teachers promoted their interest to learn.

\section{Conclusion}

The findings of this study revealed that both Peer Tutoring and Explicit instructional strategies had significant positive effect on Science and Technical College students' achievement and retention. 


\section{Recommendation}

Based on the findings of this study, it was recommended that; Science and Technical college teachers should incorporate Peer Tutoring and Explicit instructional strategies into the teaching of Science and Technical subjects in Science and Technical Colleges.

\section{References}

[1] Agboola, O. S., \& Oloyede, E. O. (2013). Effects of concept mapping and peer-tutoring instructional startegies on learning outcomes of students in chemistry. Journal of Education and Scientific Research, 3(1), 20-29.

[2] Agoro, A. A. (2012). Effects of reflective-reciprocal teaching and reflective-reciprocal peer tutoring strategies on pre-service teachers' achievement and science process skills in integrated science. A seminar paper presented at the joint staff/students' seminar series, Department of Teacher Education, Faculty of Education, University of Ibadan.

[3] Agu, P. A. \& Samuel, I. R. (2018). Effect of reversed jigsaw, tai cooperative and guided discovery instructional strategies on basic science and technology students' interest and achievement. International Journal of Innovative Education Research, 6(2), 19-26.

[4] Agu, P. A., \& Samuel, I. R. (2018). Effect of peer tutoring instructional strategy on achievement of Basic Science and Technology students with learning disabilities in Nasarawa State, Nigeria. East African journal of Education, Humanities and Literature; 1(2), 47-54.

[5] Ajila, P. K. (2003). Comparative effects of explicit and enhanced-explicit teaching on learning outcomes in primary school science in Ikere-Ekiti Local Government Area, Ekiti State, Nigeria. Ph.D thesis, Department of Teacher Education, Faculty of Education, University of Ibadan.

[6] Akani, O. (2017). Effect of guided discovery method of instruction and students' achievement in chemistry at the secondary school level in Nigeria. International Journal of Scientific Research and Education, 5(2), 6226-6234.

[7] Alabi, O.A. (2014). Effect of activity based teaching strategy on students' achievement on secondary school students in Chemistry. Journal of Education and Policy review; 6(2), 119-128.

[8] Amoo, S. A. (2013). Gender, cultural issues and achievement in secondary school mathematics: Implication for female Education. In A. O. U. Onuka (Ed), Learning (156-165). Ibadan: SPARE.

[9] Annis, L. F. (2013). The processes and effects of peer tutoring. Human Learning, 10(1), 39-47.

[10] Asogwa, U.D., Muhammed, A., Asogwa, E.N. \& Ofoegbu, T.O. (2016). Effect of interactive computer simulation package on senior secondary school students' achievement and retention in genetics concepts. Asian Journal of Information Technology. 15(14), 2313-2321.

[11] Bissonnette, S., Richard, M., Gauthier, C. \& Bouchard, C. (2010). Quelles sont les stratégies d'enseignement efficaces favorisant les apprentissages fondamentaux auprès des élèves en difficulté de niveau élémentaire? Résultats d'une méga-analyse. Revue de recherche appliquée sur l'apprentissage, 3 (1), 1-35. Accessed from: http://www.ccl-cca.ca/pdfs/JARL/JarlVol3Article1.pdf

[12] Bukunola, B.A.J. \& Idowu, O.D. (2012). Effectiveness of cooperative learning strategies on Nigerian junior secondary students' academic achievement in Basic Science. British Journal of Education, Society and Behavioural Science. 2(3), 307-325.

[13] Federal Republic of Nigeria (2012). National policy on science and technology. Lagos: NERDC Press.

[14] Federal Republic of Nigeria (2014). National policy on education. NERDC Press Lagos.

[15] Fuchs, D., Fuchs L. S., Mathes, P. G., \& Martinez, E. A. (2002). Preliminary evidence on the social standing of students with learning disabilities in PALS and no-PALS classrooms. Learning Disabilities Research \& Practice, 17(4), 205-215. doi:10.1111/1540-5826.00046 
[16] Gauthier, C., Bissonnette,S. \& Richard, M (2013). Enseignement explicite et la réussite des élèves. La gestion des apprentissages. Québec, Canada: Éditions du Renouveau Pédagogique Inc. (ÉRPI).

[17] Gauthier, C., Mellouki, M., Simard, D., Bissonnette, S. et Richard, M. (2004). Interventions pédagogiques efficaces et réussite scolaire des élèves provenant de milieux défavorisés. Une revue de littérature. Rapport de recherche préparé pour le Fonds québécois de la recherche sur la société et la culture. Québec, Québec: Université Laval.

[18] Gambari, I.A. \& Yusuf, O.M. (2017). Relative effectiveness of computer-supported Jigsaw II, STAD and TAI cooperative learning strategies on performance, attitude and retention of secondary school students in Physics. Journal of Peer Learning 10:76-94.

[19] Hartman, G. (2010). Peer learning and support via audio-teleconferencing in continuing education for nurses. Distance Education, 11(2), 308-319. doi:10.1080/0158791900110209

[20] Igboegwu, E. N., \& Okonkwo, I. G. A. (2012). Influence of gender and location of school on students' achievement in chemistry. Journal of Research in Education, 1(1), 1-14.

[21] Kabutu, F.R., Oloyede, O.I. \& Bandele, M.F. (2015). An investigation into the achievement of junior secondary school students taught integrate science using the cooperative learning strategy in Nigeria. European Journal of Physics and Chemistry, 7(2), 63-73.

[22] Kola, A. J., \& Taiwo, A. K. (2013). Analysis of gender performance in physics in Colleges of Education, Nigeria. Journal of Education and Practices, 4(6), 1-5.

[23] Moreneo, C., \& Duran, D. (2002). Frameworks: Cooperative and collaborative methods. Barcelona, Spain: Edebe.

[24] Nwadinigwe, I. P., \& Azuka-Obieke, U. (2012). The impact of emotional intelligence on academic achievement of senior secondary school students in Lagos, Nigeria. Journal of Emerging Trends in Educational Research and Policies Studies (JETERAPS), 3(4), 395-401.

[25] Olagunju, A. M., \& Babayemi, J. O. (2014). Effects of enhanced teaching (explicit teaching + peertutoring) strategy and gender on students' attitude to basic science. Journal of Education and Leadership Development, 6(2), 150-165.

[26] Oni, J.O. (2014). Teacher method of teaching and student academic achievement in Basic Science and Technology in junior secondary schools in South-West, Nigeria. Journal of Education and Social Research, 4(3), 397-402.

[27] Osokoya, M.M. (2013). Teaching methodology in basic science and technology classes in SouthWest Nigeria. Asian Journal of Education, 1(4), 206-214.

[28] Oviawe, J. I. (2008). Effect of peer tutoring assisted instruction on students' academic achievement in introductory technology. FCT Education Secretariat Journal of Curriculum studies and Instruction, 1(1), 77-84.

[29] Samuel, I. R., \& Sambo, M. H. (2019). Effects of peer tutoring and reversed jigsaw instructional strategies on senior secondary school Science students' interest and achievement in Katsina State, Nigeria. International Journal of Innovative Social \& Science Education Research, 7(1), 1-7.

[30] Samuel, I. R. (2018). Effect of reversed jigsaw cooperative instructional strategy on upper basic 2 Basic Science students' interest, attitude and achievement in thermal energy. International Journal of Scientific and Education Research, 2(5), 73-83.

[31] Whitman, N. A. (2012). Peer teaching: To teach is to learn twice. Washington, DC: ERIC Clearinghouse on Higher Education.

\footnotetext{
*Corresponding author.

E-mail address: ashlameagu@ yahoo.com
} 